\title{
Seasonal distribution of gastrointestinal nematode infections in sheep in a semiarid region, northeastern Brazil
}

\author{
Distribuição sazonal de infecção por nematóides gastrintestinais em \\ ovinos em área semiárida, Nordeste do Brasil \\ Maria de Fátima de Souza ${ }^{1,3 *}$; Manoel Pimentel-Neto ${ }^{1}$; André Luís Santos de Pinho²; \\ Rízia Maria da Silva ${ }^{1}$; Albeísa Cleyse Batista Farias ${ }^{1}$; Marcos Pezzi Guimarães ${ }^{3}$
}

\begin{abstract}
${ }^{1}$ Departamento de Microbiologia e Parasitologia, Universidade Federal do Rio Grande do Norte - UFRN, Natal, RN, Brasil
${ }^{2}$ Departamento de Estatística, Universidade Federal do Rio Grande do Norte - UFRN, Natal, RN, Brasil

${ }^{3}$ Programa de Pós-graduação em Parasitologia, Instituto de Ciências Biológicas, Universidade Federal de Minas Gerais - UFMG, Belo Horizonte, MG, Brasil
\end{abstract}

Received February 15, 2013

Accepted June 24, 2013

\begin{abstract}
The objective of this study was to determine the seasonal distribution and gastrointestinal nematode parasite load in crossbred Santa Inês tracer lambs, and to correlate the rainfall during the study period with occurrences of parasitic infections. Sixty-four male tracer lambs between the ages of four and eight months were used in the study. Two tracer lambs were inserted into the herd every 28 days to determine the pattern of infective larvae available in the environment. Variation in the fecal egg count (FEC) of nematodes was observed at the study site, with many samples containing undetectable parasite loads during the dry season. The larvae identified in coprocultures were Haemonchus sp., Trichostrongylus sp., Cooperia sp., Strongyloides sp. and Oesophagostomum sp. The nematodes recovered at necropsy were Haemonchus contortus, Trichostrongylus colubriformis, Cooperia punctata, C. pectinata, Trichuris sp., Oesophagostomum sp. and Skrajabinema ovis. The total number of larvae and the total number of immature and adult forms recovered from the tracers showed seasonal distributions that significantly correlated with the amount of rainfall received that month ( $\mathrm{p}$ value $\cong 0.000$ in all cases). The species $H$. contortus was predominant in the herd and should be considered to be main pathogenic nematode species in these hosts under these conditions.
\end{abstract}

Keywords: FEC, tracer animals, Haemonchus contortus, Trichostrongylus spp., Cooperia spp.

\section{Resumo}

O objetivo deste estudo foi determinar a distribuição sazonal e a carga parasitária de nematóides gastrintestinais em cordeiros traçadores, mestiços da raça Santa Inês, e relacionar a ocorrência dessas infecçôes com a variável chuva no mês. Foram utilizados 64 animais, machos, com idade variando entre quatro e oito meses. Em intervalos de 28 dias, dois traçadores foram inseridos no rebanho para determinar o padrão de disponibilidade de larvas infectantes no ambiente. Variaçấo na contagem de ovos por grama (OPG) de nematóides foi observada no local do estudo, com alta frequência de amostras com carga parasitária indetectável no período seco. Das coproculturas foram identificadas larvas de Haemonchus sp., Trichostrongylus sp., Cooperia sp., Strongyloides sp. e Oesophagostomum sp. Os nematóides recuperados à necropsia foram Haemonchus contortus, Trichostrongylus colubriformis, Cooperia punctata, C. pectinata, Trichuris sp., Oesophagostomum sp. e Skrajabinema ovis. O total de larvas, de formas imaturas e de adultos recuperados dos traçadores, mostraram distribuição sazonal significativamente relacionada com a ocorrência de chuva no mês (valor-p $\cong 0,000$, para todos os casos). A espécie $H$. contortus foi predominante no rebanho e deve ser considerada a espécie de nematóide mais importante nesses hospedeiros, sob as condiçôes do estudo.

Palavras-chave: OPG, animais traçadores, Haemonchus contortus, Trichostrongylus spp., Cooperia spp.

\footnotetext{
${ }^{*}$ Corresponding author: Maria de Fátima de Souza

Departamento de Microbiologia e Parasitologia, Centro de Biociências,

Universidade Federal do Rio Grande do Norte - UFRN, Av. Senador Salgado

Filho, 3000, Lagoa Nova, Campus Central da UFRN, CEP 59072-970,

Natal, RN, Brasil

e-mail: mfsouza@cb.ufrn.br
} 


\section{Introduction}

The sheep industry is a traditional activity comprising small farms and subsistence animal-rearing in the northeastern region of Brazil (JESUS-JUNIOR et al., 2010; SIMPLÍCIO et al., 2003), and $56.7 \%$ of the national sheep flock is found there (IBGE, 2010).

This activity provides an alternative supply of meat and dairy products, thus contributing towards improving the food quality of the rural population and keeping people settled on the land (LEITE, 2004). Nevertheless, it has not ensured availability of these animals for industrial production. The reasons range from climatic conditions to inappropriate herd handling.

With regard to sanitary management, one of the most important issues in connection with the sheep industry is infection by parasites of the sheep's gastrointestinal tract (VIEIRA et al., 1997; SILVA et al., 1998), since these can cause metabolic and systemic changes that affect animal growth and milk and wool production (DARGIE; ALLONBY, 1975; HOLMES, 1987; FOX, 1997).

In animals on pasture, the majority of these infections are mixed (SOUZA et al., 2012), even if the impact depends on the intensity of the infection and the host's immune and physiological status.

Implementation of appropriate management practices for promoting animal health is a real challenge for breeders worldwide. Use of anthelmintic treatment has been questioned because of the emergence of parasite strains that are resistant to the drugs commonly used (MELO et al., 2003). Moreover, growing numbers of consumers are demanding animal products that are free of pathogens and any chemical residues (KRAMER; THAMSBORG, 2007). In addition, climate change will probably cause changes to both the epidemiology and the intensity of parasite infections (WALTHER et al., 2002).

To support management practices, epidemiological knowledge about the more prevalent and more pathogenic parasite species in each region is needed. Therefore, the objectives of this study were to determine the seasonal distribution and parasite load of gastrointestinal nematodes in tracer lambs and to correlate the rainfall during the study period with occurrences of parasitic infections.

\section{Materials and Methods}

\section{Study area and herd management}

The field study was conducted on the São Vicente farm in the municipality of Lajes (5 $42^{\prime} 00^{\prime}$ 'south and $36^{\circ} 14$ ' 41" west), Rio Grande do Norte, Brazil (Figure 1), from March 2005 to August 2007.

The field study area has a semiarid climate with low precipitation that is irregular and occurs mainly between January and June (Figure 2). The predominant vegetation is hyperxerophilous caatinga with an abundance of cacti and shrubs. The pasture area comprised 897 hectares, divided into four plots, on which sheep of different age groups were allowed to graze. The native vegetation constituted the staple food for the flock. The farm also had a small number of cattle that did not graze in the same locations as the sheep.

The farm had a herd of approximately 1,200 predominantly crossbred Santa Inês sheep (Ovis aries), of which around 750 were breeding females and 20 were breeding males. These males comprised one Dorper, one Morada Nova and 18 Santa Inês sheep.

The animals that were being finished were provided with water and mineral salt ad libitum. Twice a day, these animals received a commercial concentrate specific for fattening sheep (186 g/animal). Furthermore, their diet was supplemented with a mixture of salt and sugar cane molasses.

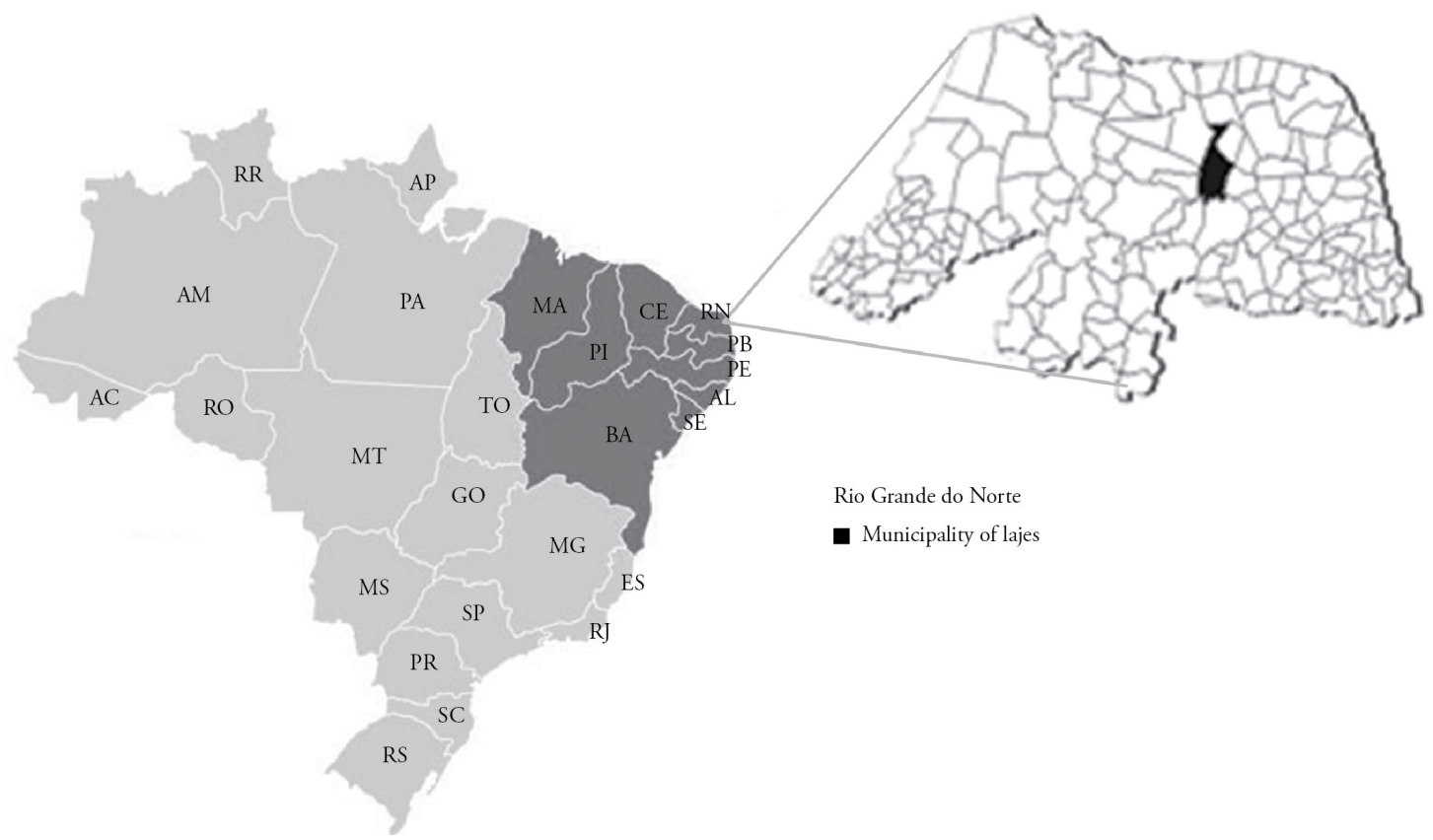

Figure 1. Northeastern region of Brazil, state of Rio Grande do Norte and municipality of Lajes, where the samples were collected. 
Anthelmintic treatment was administered to the lambs before confinement and to the pregnant sheep, when deemed necessary. For the remainder of the herd, this was done at the beginning of the rainy season and when there were clinical signs of helminthiasis. The drugs used were albendazole and Ripercol L.

The breeding scheme was continuous, but with a greater number of births during the rainy season. After birth, the lambs were identified and allowed to feed at the udder for two months.

\section{Experimental animals and collection and processing of fecal samples}

Two helminth-free tracer lambs were introduced into the herd every 28 days. These animals were crossbred Santa Inês males (four to eight months of age). Samples were collected from the tracer lambs on day 1 (before anthelmintic treatment: B-ttt), day 14 (after anthelmintic treatment: A-ttt) and day 44 (before autopsy: Aut).

Feces were collected directly from the rectum, placed individually in polypropylene collectors and transported to the lab in coolers containing ice cubes. The fecal egg count (FEC) of nematodes was determined by means of the modified McMaster technique (UENO; GONÇALVES, 1988). Each sample was coprocultured, and 100 larvae were identified per sample (WYK et al., 2004).

\section{Tracer animals and procedure}

The tracer lambs were treated with albendazole (Albendazol, Labovet) at a dose of $3.8 \mathrm{mg} / \mathrm{kg}$ of live weight and levamisole hydrochloride (Ripercol L, Fort Dodge, Brazil): 5.0-7.5 mg/kg for animals that weighed $10-15 \mathrm{~kg}$ and $7.5-10.0 \mathrm{mg} / \mathrm{kg}$ for animals that weighed $16-20 \mathrm{~kg}$. The animals were held in quarantine for 14 days to confirm that they were free from nematodes. The tracers were introduced into the herd and allowed to graze for 28 days. They were then put into stalls for two days, and on the $44^{\text {th }}$ day of the experiment, the animals were weighed, slaughtered and autopsied.

This work scheme led to occurrences of two autopsies in months with 31 days (August 2005 and August 2006). Also, there were two autopsies in February 2006, but in this case it was due to adjustments to the farm's work schedule.

The gastrointestinal tract was removed and separated into three sections: abomasum, small intestine and large intestine. The abomasum was opened longitudinally, along the greater curvature, using scissors. The contents of the abomasum were collected in a plastic receptacle and the mucosal surface was immediately washed with warm (about $30^{\circ} \mathrm{C}$ ) mammalian Ringer's solution using moderate pressure. The contents and the wash solution were packed in an aluminum container at room temperature for 30 minutes prior to fixation. Each section of the intestine was opened longitudinally using an enterotome and then washed.

The abomasum and small intestine were distended across stainless steel screens and the mucosal surfaces were brought into contact with mammalian Ringer's solution at $37^{\circ} \mathrm{C}$ for two hours in a stainless steel container. The liquid was then passed through a metal sieve with $38 \mu \mathrm{m}$ pores and the material retained in the sieve was added to the contents of the corresponding organ (UENO; GONÇALVES, 1988).
The final volume from each segment of the digestive tract was hot-fixed $\left(60^{\circ} \mathrm{C}\right)$ at a ratio of one part formaldehyde for every ten parts of intestinal contents, as described by Anderson and Verster (1971).

The fixed material from the abomasum and small intestine was passed through a metal sieve with $38 \mu \mathrm{m}$ pores, and the fixed material from the large intestine was passed through a metal sieve with $150 \mu \mathrm{m}$ pores under a strong stream of water. All of the material retained in the sieves (including nematodes) was stained with an aqueous iodine solution and examined under a stereomicroscope. The nematodes of the gastrointestinal tract were separated and quantified (EYSKER; KOOYMAN, 1993), and were then clarified in a lactophenol solution for species identification.

The data were expressed as prevalences and mean intensities. The prevalence was the number of hosts infected with one or more individuals of a particular parasite species, divided by the number of hosts examined for that parasite species. The mean intensity was the total number of parasites of a particular species found in a sample, divided by the number of hosts infected with that parasite (BUSH et al., 1997).

\section{Weather data}

Climatological reference values for maximum temperature, minimum temperature and relative humidity were obtained from EMPARN (Empresa de Pesquisa Agropecuária do Rio Grande do Norte).

The monthly amounts of rain over the course of the study period were obtained from the EMPARN weather station located in the urban center of the municipality.

\section{Statistical analysis}

The statistical analysis was conducted using the $\mathrm{R}$ software, version 3.0.1, with the statistical significance level set at $\mathrm{p}<0.05$. The variable of rainfall during the month was defined as the total rainfall $(\mathrm{mm})$ during the thirty days prior to fecal sample collection. The relationships between the independent variable of rainfall during the month and other dependent variables were analyzed using a Poisson regression. The dependent variables examined were the FEC of nematodes, the number of Haemonchus sp. larvae in the coprocultures and the total number of nematodes recovered from the autopsy. The Haemonchus sp. larvae were taken into consideration in the statistical analysis because they presented greater prevalence and intensity in the coprocultures.

The relationship between the variable of the animals' weights (continuous variable) and the variables of rainfall during the month and total number of nematodes recovered at autopsy were analyzed by means of linear regression.

\section{Results}

\section{Fecal egg count and coprocultures}

A total of 64 animals were examined prior to receiving anthelmintic treatment; 58 of these animals were slaughtered and 


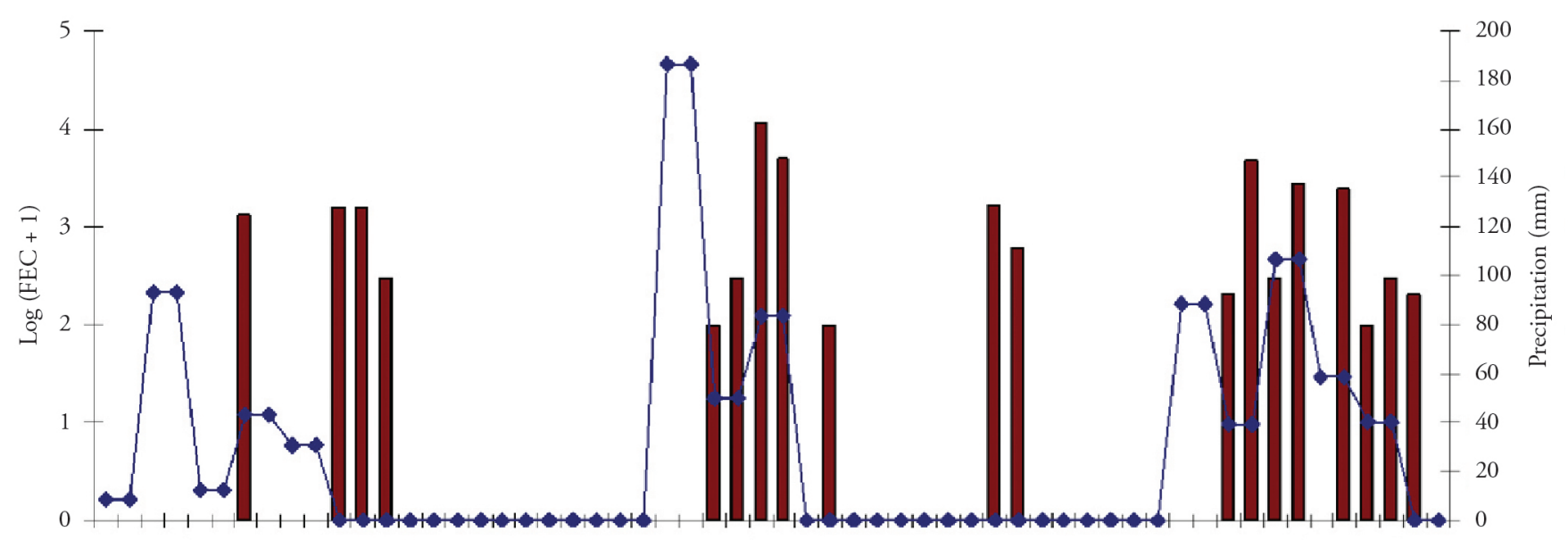

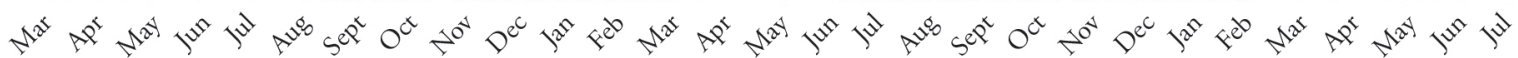

Figure 2. Temporal distribution of eggs from the feces of tracer lambs in samples collected before anthelmintic treatment, in relation to the rainfall during that month; samples were collected between March 2005 and July 2007 in the municipality of Lajes, Rio Grande do Norte, Brazil.

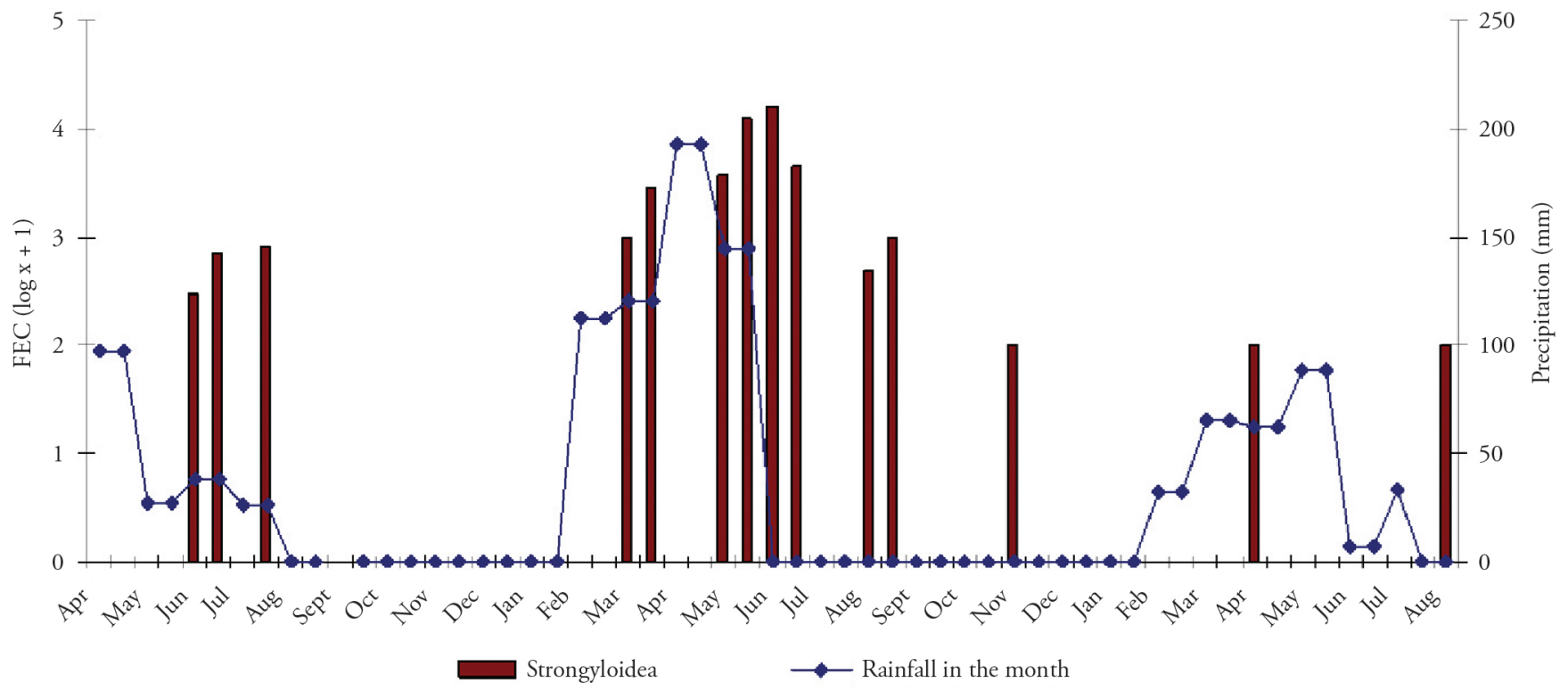

Figure 3. Temporal distribution of eggs from the feces of tracer lambs in samples collected at autopsy, in relation to the rainfall during that month; samples were collected between April 2005 and August 2007 in the municipality of Lajes, Rio Grande do Norte, Brazil.

autopsied. One animal (no. 32) that should have been autopsied in September 2005 died before the scheduled date for autopsy. Another animal (no. 165) disappeared from the herd in July 2007, and was never found.

The FEC from the animals sampled before treatment ranged from 100 to 11,800 and the FEC from the animals autopsied ranged from 100 to 16,000. In both cases, the FEC of nematodes did not show any significant relationship with variation in rainfall.

In order to have a better overall view of the data, we chose to transform the data to a more suitable scale. Thus, the FEC data were transformed into $\log _{10}(x+1)$ form, where $\mathrm{x}$ represented the FEC for each animal. Moreover, to avoid occurrences of $\log _{10}$ (0), we added one unit to all the FEC values (Figures 2 and 3).

The coprocultures from the 64 animals sampled before treatment were positive for Haemonchus sp. (25.0\%), Trichostrongylus sp. (4.7\%) and Oesophagostomum sp. (9.4\%). The coprocultures from the 58 animals autopsied were positive for Haemonchus sp. (44.4\%), Trichostrongylus sp. (22.2\%), Cooperia sp. (3.7\%), Strongyloides sp. and Oesophagostomum sp. (1.9\%). The variable of rainfall showed significant relationships with the presence of Haemonchus sp. larvae in the coprocultures of material collected before treatment $(p$ value $\cong 0.000)$ and at autopsy ( $p$ value $\cong 0.000$ ). 
The animals whose coprocultures were positive in samples collected after anthelmintic treatment were excluded from necropsies. These animals were no. 33, which should have been autopsied in September 2005 (coproculture with larvae of Trichostrongylus); no. 54 and no. 55A, which should have been autopsied in July 2006; and no. 67, which should have been autopsied in November 2006 (in both cases with positive coprocultures for Haemonchus).

\section{Helminths present in tracers}

A total of 14,646 nematode specimens were recovered during the study, including both adult and immature forms (Table 1). $H$. contortus represented $84.2 \%$ of the nematodes collected, with a total of 12,332 specimens, a range from 1 to 4,809 nematodes isolated from each animal and an average of 212.6 nematodes/ animal (Figure 4). The prevalence of immature Haemonchus ( $\mathrm{L}_{4}$ final) was $20.7 \%$.

Trichostrongylus sp. represented 12.9\%, Cooperia sp. 1.4\%, Trichuris sp. 0.6\% and Oesophagostomum sp. 0.04\% (Figure 5 and Figure 6). S. ovis represented $0.007 \%$, with only one specimen (Table 1).

The number of nematodes isolated from each tracer animal ranged from 1 to 5,588, with the greatest variation found in Haemonchus sp. The variation in rainfall showed a significant relationship with the total number of nematodes recovered during the autopsy ( $\mathrm{p}$ value $\cong 0.000$ )

Table 1. Prevalence and mean intensity of nematodes recovered from autopsied tracer lambs; samples were collected between April 2005 and August 2007 in the municipality of Lajes, Rio Grande do Norte, Brazil.

\begin{tabular}{|c|c|c|c|c|c|c|c|c|c|c|c|c|c|}
\hline \multirow{2}{*}{$\begin{array}{c}\text { Nematodes } \\
\text { Genus/Specie }\end{array}$} & \multirow{2}{*}{$\begin{array}{c}\text { Prevalence } \\
\%\end{array}$} & \multicolumn{12}{|c|}{ Mean Intensity } \\
\hline & & $\begin{array}{l}\text { Jan } \\
(4)\end{array}$ & $\begin{array}{c}\text { Feb } \\
\text { (6) }\end{array}$ & $\begin{array}{c}\text { Mar } \\
\text { (4) }\end{array}$ & $\begin{array}{c}\text { Apr } \\
\text { (6) }\end{array}$ & $\begin{array}{c}\text { May } \\
(6)\end{array}$ & $\begin{array}{c}\text { June } \\
(6)\end{array}$ & $\begin{array}{l}\text { July } \\
\text { (3) }\end{array}$ & $\begin{array}{l}\text { Aug } \\
\text { (10) }\end{array}$ & $\begin{array}{l}\text { Sept } \\
\text { (2) }\end{array}$ & $\begin{array}{l}\text { Oct } \\
\text { (4) }\end{array}$ & $\begin{array}{l}\text { Nov } \\
\text { (3) }\end{array}$ & $\begin{array}{c}\text { Dec } \\
\text { (4) }\end{array}$ \\
\hline H. contortus & 62.9 & 0 & 0 & 363.5 & 208.5 & 475 & 1026.8 & 40.6 & 7.3 & 0 & 0.8 & 22.3 & 0 \\
\hline Haemonchus sp. ( $\mathrm{L}_{4}$ last) & 19.4 & 0 & 0 & 33.0 & 0.5 & 16.7 & 0 & 0 & 0.7 & 0 & 0 & 0 & 0 \\
\hline Cooperia sp. & 6.5 & 0 & 0 & 0 & 0 & 0.2 & 0 & 0 & 0.4 & 0 & 0 & 0 & 0 \\
\hline Cooperia pectinata & 6.5 & 0 & 0 & 30.0 & 0.2 & 6.5 & 0.2 & 0 & 0 & 0 & 0 & 0 & 0 \\
\hline Cooperia punctata & 11.3 & 0 & 0 & 0.5 & 2.0 & 0.5 & 3.0 & 0 & 0 & 0 & 0 & 0 & 0 \\
\hline Trichostrongylus sp. & 11.3 & 0 & 0 & 0.5 & 0.3 & 0 & 0.3 & 0 & 1.3 & 0 & 0 & 0 & 0 \\
\hline T. colubriformis & 21.0 & 0 & 0 & 2.3 & 3.8 & 122.3 & 126.8 & 0 & 34.7 & 0 & 0 & 0 & 0 \\
\hline Oesophagostomum sp. (L4 initial) & 1.6 & 0 & 0 & 0 & 0.5 & 0 & 0 & 0 & 0 & 0 & 0 & 0 & 0 \\
\hline Oesophagostomum sp. (L4 last) & 8.1 & 0 & 0 & 0 & 2.8 & 0.5 & 0 & 0 & 1.9 & 0 & 0 & 0 & 0 \\
\hline S. ovis & 1.6 & 0 & 0 & 0.3 & 0 & 0 & 0 & 0 & 0 & 0 & 0 & 0 & 0 \\
\hline Trichuris sp. & 27.4 & 0.3 & 0.7 & 1.3 & 0.8 & 0 & 0 & 0 & 2.4 & 0.5 & 0 & 4.8 & 6.5 \\
\hline
\end{tabular}

( ) Total number of autopsied animals.

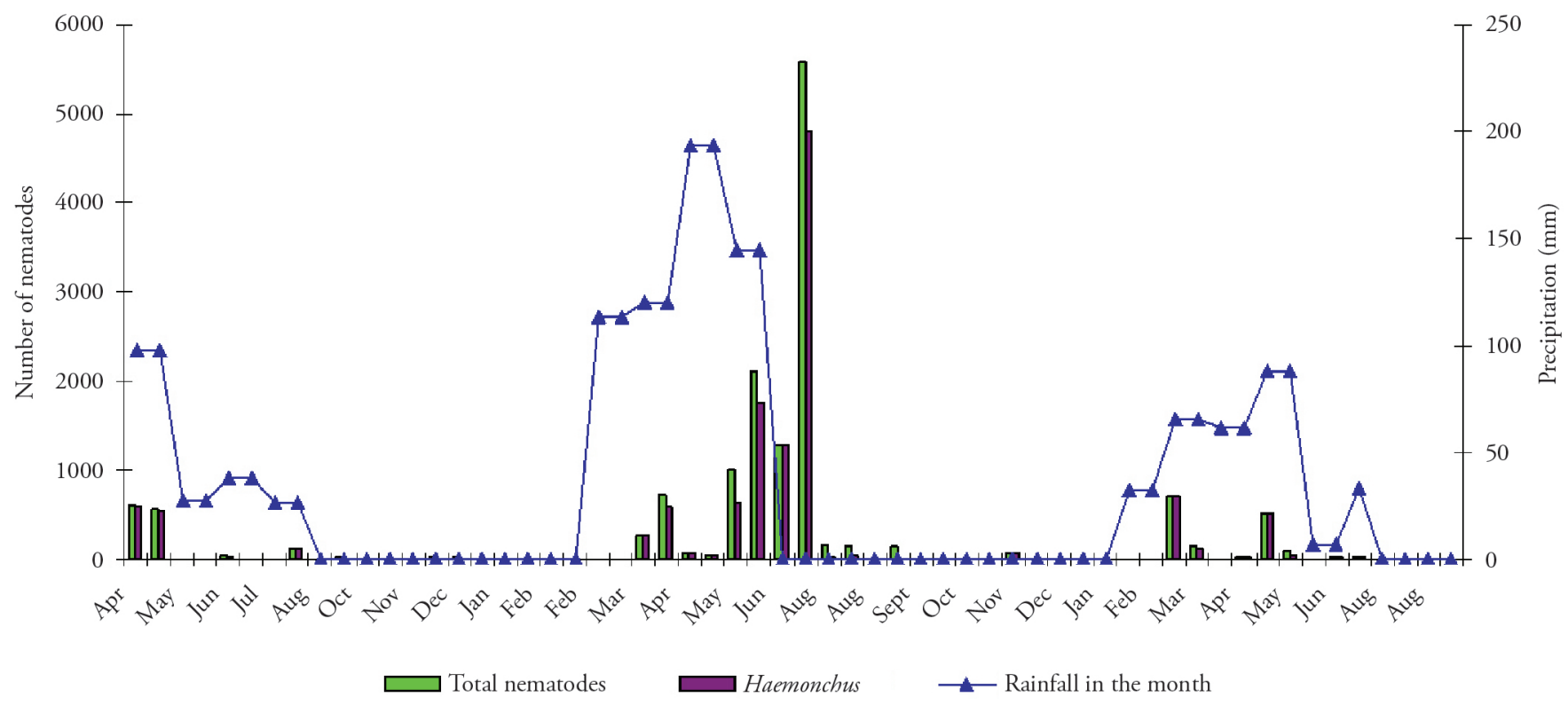

Figure 4. Temporal distribution of the numbers of gastrointestinal nematodes and $H$. contortus recovered from autopsied tracer lambs, in relation to the rainfall during that month; samples were collected between April 2005 and August 2007 in the municipality of Lajes, Rio Grande do Norte, Brazil. 


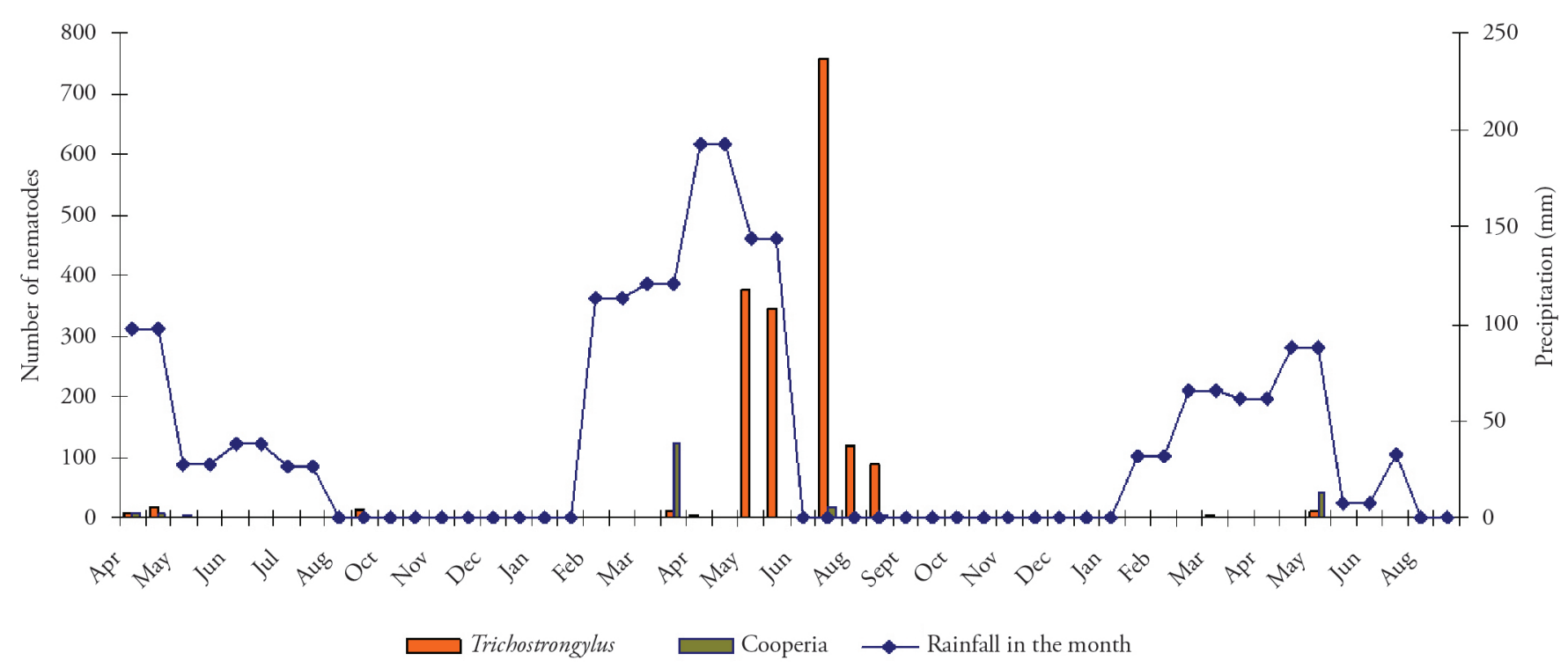

Figure 5. Temporal distribution of Trichostrongylus sp. and Cooperia sp. recovered from autopsied tracer lambs, in relation to the rainfall during that month; samples were collected between April 2005 and August 2007 in the municipality of Lajes, Rio Grande do Norte, Brazil.

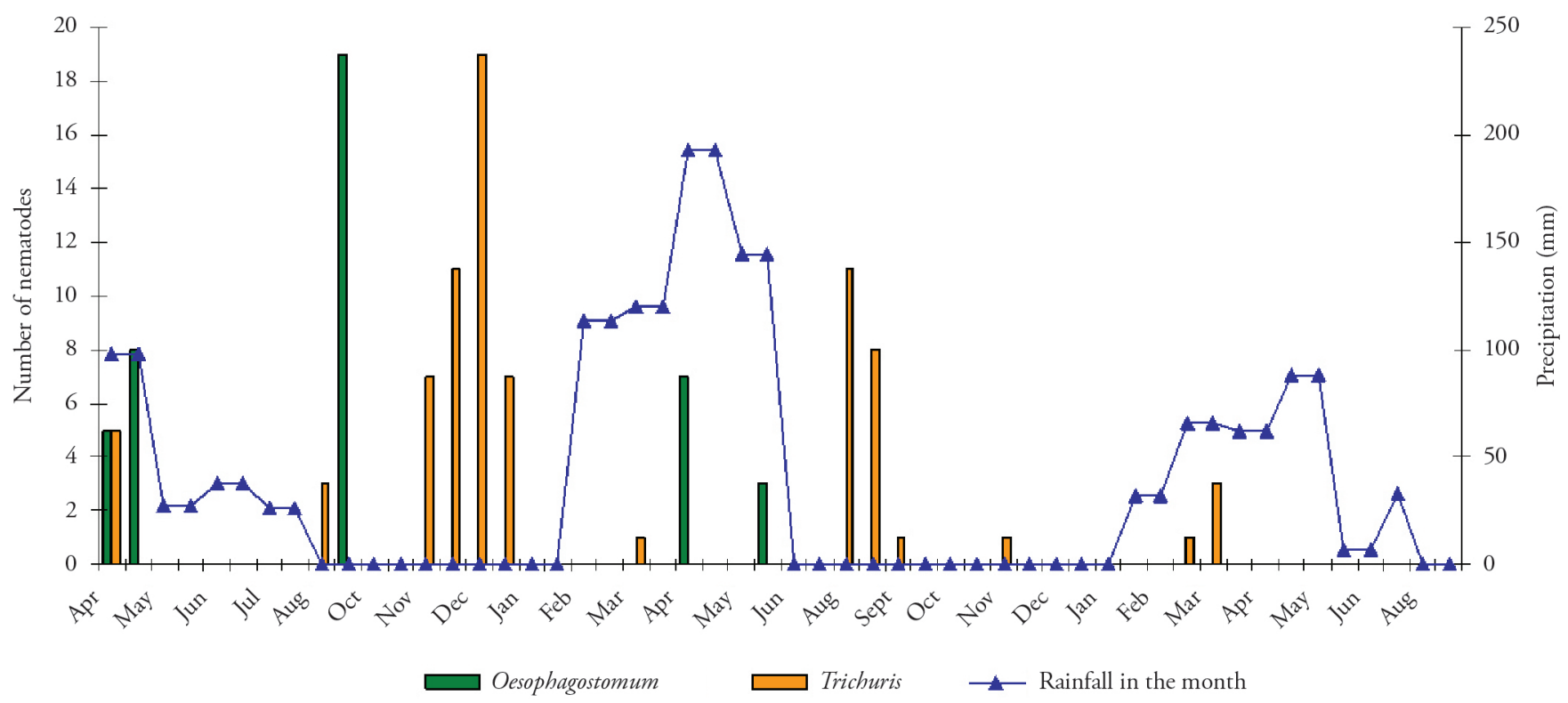

Figure 6. Temporal distribution of Oesophagostomum sp. and Trichuris sp. recovered from autopsied tracer lambs, in relation to the rainfall during that month; samples were collected between April 2005 and August 2007 in the municipality of Lajes, Rio Grande do Norte, Brazil.

The weights of the animals autopsied ranged from 10 to $26 \mathrm{~kg}$, with a mean weight of $18.0 \mathrm{~kg}(\mathrm{~s}=4.17)$ and a median of $19 \mathrm{~kg}$. The variable of the animals' weights was unrelated to the variations in rainfall and to the total number of nematodes recovered during the autopsy.

The climatological data are shown in Figure 7 . The temperature maxima ranged from 29.2 to $32.2^{\circ} \mathrm{C}$ (July and January, respectively). The minimum temperature ranged from 23.6 to $26.2^{\circ} \mathrm{C}$ (July and February, respectively). Relative humidity ranged from $60.0 \%$ to 81.0\% (September and April, respectively).

\section{Discussion}

The great variation in the FEC in tracer lambs was due to the occurrence of a few cases with high numbers of parasites (UENO; GONÇALVES, 1988) and the high frequency of samples in which parasite loads were not detected. A previous study on Santa Inês lambs in São Paulo, Brazil, showed a FEC that remained below 1,000 during an experiment that lasted for more than ten months (AMARANTE et al., 2004). 


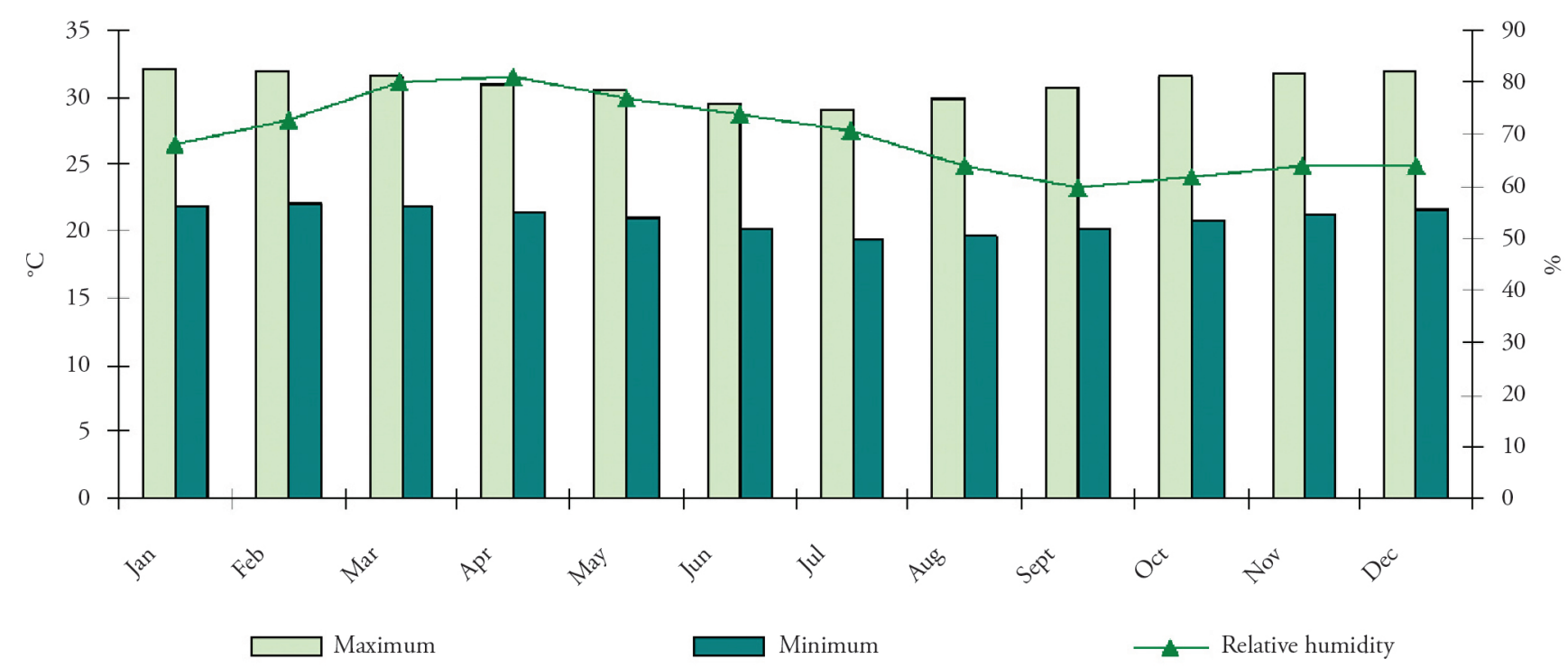

Figure 7. Estimated temperature $\left({ }^{\circ} \mathrm{C}\right)$ and relative humidity $(\%)$ data between January and December 2006, in the municipality of Lajes, Rio do Norte, Brazil.

The greatest parasite load detected by the FEC came from samples obtained during the rainy season (the period from the onset of the rains until about two months after the end). This pattern agrees with the findings from other studies, even those conducted under different climatic conditions (LIMA, 1998; AGYEI et al., 2004).

Haemonchus sp. larvae were the predominant larvae identified in the coprocultures, followed by Trichostrongylus sp., Oesophagostomum sp., Cooperia sp. and Strongyloides sp. Oesophagostomum sp. larvae were only found in samples collected before anthelmintic treatment, because of the peculiar traits of this parasite's life cycle (DASH, 1973; BRITO et al., 1996, PIMENTEL-NETO et al., 1999).

Coprocultures on some of the samples collected after treatment were positive. This indicates that these nematodes may have been resistant to both anthelmintics used in this experiment.

The occurrences of Haemonchus sp. larvae were discontinuous and statistically related to variations in monthly rainfall. Strongyloides sp. larvae were seen only in one sample, which was collected during the autopsy (no. 56). This animal was four months old at the beginning of the experiment and six months old at the time of the autopsy and also had a low weight $(11 \mathrm{~kg})$. In this case, young age and nutritional deficiencies may have been factors contributing towards establishment of this infection. S. papillosus has been found in goats aged five to six months (SILVA et al., 1998).

The degree of infection due to Haemonchus spp. in sheep can be considered light when the total number of nematodes recovered is less than 500 , moderate when it is between 500 and 1,500 , heavy when it is greater than 1,500 and fatal when it is more than 3,000 (UENO; GONÇALVES, 1988). According to these parameters, the parasite loads in this study were light for most of the animals.

Interpreting the significance of the parasitic load is a challenge. In naturally infected Corriedale lambs, between 12 and 8,943 specimens of Haemonchus were recovered per lamb, but the secretory epithelium was intact in all animals (OLIVEIRA-SEQUEIRA et al., 2000; REINECKE; GROENEVELD, 1991). However, it seems that low parasite loads have pathogenic significance in arid and semiarid regions (MORALES et al., 2001).

$H$. contortus was the species that was most prevalent and also the species that reached the greatest parasite load in the host. In the semiarid climatic conditions of Brazil, this species has also frequently been found in tracer goats, with a prevalence that varies among studies (CHARLES, 1989; VIEIRA et al., 1997). This indicates that $H$. contortus is able to survive at high temperatures and low relative humidity.

Immature forms of $H$. contortus were found only as $\mathrm{L}_{4}$ last, thus indicating that this study found no evidence of hypobiosis. The source of infection for the tracer lambs must have been the animals of the herd.

The second most frequently identified and abundant nematode found in autopsied animals was T. colubriformis, which is in agreement with other studies conducted on sheep (VIEIRA et al., 1997) and goats (SILVA et al., 1998) in this region.

Two species of Cooperia were observed: C. punctata was the most prevalent and C. pectinata had greater intensity in infections. Almost one third of the tracer lambs were infected with Trichuris sp., but the mean intensity of these infections was low. Infections with Oesophagostomum sp. occurred at low frequency and with low intensity. Studies on the prevalence of the species $O$. columbianum in goats in northeastern Brazil have reported a range from 22.6\% (VIEIRA et al., 1997) to $87.0 \%$ (CHARLES, 1989).

Occurrences of nematodes in the tracers, other than Trichuris, were observed from around one month after the beginning of the rains until around two months after the end of the rains, when it was still possible to find infecting larvae on the pasture. In November 2006, in the middle of the drought period, light rain occurred and consequently, nematode occurrences in the autopsies were observed. 
Infection by Trichuris occurs through ingestion of eggs of this nematode. These eggs are eliminated with the feces of the infected animals and are spread on the ground when the fecal matter decomposes. Because the vegetation becomes scarce and the soil is uncovered during the drought period in the semiarid region, the animals seek remnants of food in the soil and thus may come into contact with the Trichuris eggs and become infected.

The infection rate due to Trichuris is low because, even though the eggs are resistant, the climatic conditions of the semiarid region during the drought months are quite adverse, because of both the lack of rain and the relative low humidity and high temperature.

Santa Inês lambs are more resistant to helminthic infection than Suffolk and Ile de France lambs (AMARANTE et al., 2004). However, despite this resistance and the adverse weather conditions during some parts of the year, the present study revealed that helminthic infections in Santa Inês lambs can be intense during the rainy season.

In conclusion, variation in the FEC of nematodes was observed at the study site, with many samples possessing undetectable parasite loads during the dry season. The rainfall variation between the months showed a significant relationship with the number of nematodes recovered at autopsy. The species $H$. contortus occurred throughout the rainy season. It was the most prevalent and abundant species found in the tracer lambs and varied in intensity among the animals. These results showed that there is a seasonal pattern of gastrointestinal nematode infection prevalence in sheep.

\section{Acknowledgements}

To FAPERN-CNPq, for the financial support. To the technician Edson Santana, for his support during field collections. To Dr. Vicente Mesquita, for his permission to conduct this work on his property and for providing the animals used in this study. To Dr. Gilmar Bristot, for providing the climatological data.

\section{References}

Agyei AD, Odonkor M, Osei-Somuah A. Concurrence of Eimeria and helminth parasitic infections in West African Dwarf kids in Ghana. Small Ruminant Res 2004; 51(1): 29-35. http://dx.doi.org/10.1016/ S0921-4488(03)00184-6

Amarante AFT, Bricarello PA, Rocha RA, Gennari SM. Resistance of Santa Ines, Suffolk and Ile de France sheep to naturally acquired gastrointestinal nematode infections. Vet Parasitol 2004; 120(1-2): 91-106. PMid:15019147. http://dx.doi.org/10.1016/j.vetpar.2003.12.004

Anderson PJS, Verster A. Studies on Dictyocaulus filaria. I. Modifications of laboratory procedures. Onderstepoort J Vet Res 1971; 38(3): 181-184. PMid:4277675.

Brito MF, Pimentel-Neto M, Montes BMP. Aspectos clínicos em caprinos infestados experimentalmente por Oesophagostomum columbianum (Curtice, 1890). Rev Bras Med Vet 1996; 18(1): 32-42.

Bush AO, Lafferty KD, Lotz JM, Shostak AW. Parasitology meets ecology on its own terms: Margolis et al. revisited. J Parasitol 1997; 83(4): 575-583. PMid:9267395. http://dx.doi.org/10.2307/3284227
Charles TP. Seasonal prevalence of gastrointestinal nematodes of goats in Pernambuco State, Brazil. Vet Parasitol 1989; 30(4): 335-343. http:// dx.doi.org/10.1016/0304-4017(89)90103-9

Dash KM. The life cycle of Oesophagostomum columbianum (Curtice, 1890) in sheep. Int J Parasitol 1973; 3(6): 843-851. http:// dx.doi.org/10.1016/0020-7519(73)90075-1

Dargie JD, Allonby EW. Pathophysiology of single and challenge infections of Haemonchus contortus in merino sheep: studies on red cell kinetics and the "self-cure" phenomenon. Int J Parasitol 1975; 5(2): 147-157. http:// dx.doi.org/10.1016/0020-7519(75)90021-1

Eysker M, Kooyman FN. Notes on necropsy and herbage processing techniques for gastrointestinal nematodes of ruminants. Vet Parasitol 1993; 46(1-4): 205-213. http://dx.doi.org/10.1016/03044017(93)90059-V

Fox MT. Pathophysiology of infection with gastrointestinal nematodes in domestic ruminants: recent developments. Vet Parasitol 1997; 72(3-4): 285-308. http://dx.doi.org/10.1016/S03044017(97)00102-7

Holmes PH. Pathophysiology of nematode infections. Int $J$ Parasitol 1987; 17(2): 443-451. http://dx.doi.org/10.1016/00207519(87)90120-2

Instituto Brasileiro de Geografia e Estatística - IBGE. Produção da Pecuária Municipal [online]. 2010 [cited 2013 Jan 23]. Available from: http://www.ibge.gov.br/home/estatistica/economia/ppm/2010/ ppm2010.pdf.

Jesus-Junior C, Rodrigues LS, Moraes VEG. Ovinocaprinocultura de corte - a convivência dos extremos. Agroindústria. BNDES Setorial [online]. 2010 [cited 2013 Jan 23]. Available from: http://www.bndes. gov.br/SiteBNDES/export/sites/default/bndes_pt/Galerias/Arquivos/ conhecimento/bnset/set3108.pdf.

Kramer LH, Thamsborg SM. Food-borne parasitic zoonosis. Vet Parasitol 2007; 149(1-2): 1-2. PMid:17706875. http://dx.doi. org/10.1016/j.vetpar.2007.07.001

Leite ER. Ovinocaprinocultura no Nordeste - organizaçāo e crescimento. [online]. 2004 [cited 2012 Jul 27]. Available from: http://www.embrapa. br/imprensa/artigos/2000/artigo.2004-12-07.2538681592/.

Lima WS. Seasonal infection pattern of gastrointestinal nematodes of beef cattle in Minas Gerais State - Brazil. Vet Parasitol 1998; 74(2-4): 203-214. http://dx.doi.org/10.1016/S0304-4017(97)00164-7

Melo ACFL, Reis IF, Bevilaqua CML, Vieira LS, Echevarria FAM, Melo LM. Nematódeos resistentes a anti-helmíntico em rebanhos de ovinos e caprinos do Estado do Ceará, Brasil. Cienc Rural 2003; 33(2): 339-344. http://dx.doi.org/10.1590/S0103-84782003000200024

Morales G, Pino LA, Sandoval E, Moreno L. Gastrointestinal nematode infection in ewes raised in an arid zone of Venezuela. Parasitol día 2001; 25(1-2): 36-39.

Oliveira-Sequeira TCG, Amarante AFT, Sequeira JL. Parasitological characteristics and tissue response in the abomasum of sheep infected with Haemonchus spp. Arq Bras Med Vet Zootecnia 2000; 52 (5): 447-452. http://dx.doi.org/10.1590/S0102-09352000000500007

Pimentel-Neto M, Amaral BMPM, Brito MF, Fonseca AH. Parada de crescimento do ciclo evolutivo de Oesophagostomum columbianum (Curtice, 1890) em caprinos na Baixada Fluminense, Rio de Janeiro. Rev Bras Med Vet 1999; 21(4): 165-170. 
Reinecke RK, Groeneveld HT. Overberg research projects. X. Faecal egg counts in the interpretation of nematode worm burdens in sheep. Onderstepoort J Vet Res 1991; 58(3): 149-153. PMid:1923377.

Silva WW, Bevilaqua CML, Costa AL. Natural evolution of gastrointestinal nematodes in goats (Capra hircus) in the semi-arid ecosystem of the Paraíba backwoods, northeastern Brazil. Vet Parasitol 1998; 80(1): 47-52. http://dx.doi.org/10.1016/S0304-4017(98)00188-5

Simplício AA, Wander AE, Leite ER, Lopes EA. Caprino-ovinocultura de corte como alternativa para a geração de emprego e renda. Sobral: Embrapa Caprinos; 2003.

Souza MF, Pimentel-Neto M, Silva RM, Farias ACB, Guimarães MP. Gastrointestinal parasites of sheep, municipality of Lajes, Rio Grande do Norte, Brasil. Rev Bras Parasitol Vet 2012; 21(1): 71-73. http://dx.doi. org/10.1590/S1984-29612012000100015
Ueno H, Gonçalves PC. Manual para diagnóstico das helmintoses de ruminantes. 4. ed. Tokyo: Japan International Cooperation Agency; 1988.

Vieira LS, Cavalcante ACR, Ximenes LJF. Epidemiologia e controle das principais parasitoses de caprinos nas regióes semi-áridas do Nordeste. Sobral: Embrapa CNPCaprinos/MERIAL; 1997. (Série Embrapa. Circular Técnica).

Walther GR, Post E, Convey P, Menzel A, Parmesan C, Beebee TJC, et al. Ecological responses to recent climate change. Nature 2002; 416: 389 395. PMid:11919621. http://dx.doi.org/10.1038/416389a

Wyk JA, Cabaret J, Michael LM. Morphological identification of nematode larvae of small ruminants and cattle simplified. Vet Parasitol 2004; 119(4): 277-306. PMid:15154594. http://dx.doi. org/10.1016/j.vetpar.2003.11.012 